\title{
Agro-Landscape Zoning of West Georgia for Spreading New Varieties of Tangerine in Order to Reveal Optimal Natural Conditions
}

\author{
Zurab Seperteladze1, Eter Davitaia1, Shota Lamparadze², Guram Memarne³, \\ George Gaprindashvili ${ }^{1}$, Tamar Aleksidze ${ }^{1}$ \\ ${ }^{1}$ Department of Geography, Ivane Javakhishvili Tbilisi State University, Tbilisi, Georgia \\ ${ }^{2}$ Batumi Shota Rustaveli State University, Batumi, Georgia \\ ${ }^{3}$ Institute of Phytopathology and Biodiversity, Batumi Shota Rustaveli State University, Batumi, Georgia \\ Email: zura_sep@mail.ru, eteri.davitaia@yandex.ru,shota_lamparadze@yahoo.com, \\ plantimmunity@yahoo.com, gaprindashvili.george@gmail.com, aleksidze@tsu.ge
}

Received 30 October 2015; accepted 26 December 2015; published 29 December 2015

Copyright (C) 2015 by authors and Scientific Research Publishing Inc.

This work is licensed under the Creative Commons Attribution International License (CC BY). http://creativecommons.org/licenses/by/4.0/

(c) (i) Open Access

\begin{abstract}
A landscape-multifactor method has been developed and established in West Georgia for agroresource potential spatial distribution regularities for Tangerine. The emphasis was made especially for the components (relief, climate, soils), having substantial impact on the growth and yield of citrus. Morpho-metric analysis (biometric indicators, end of fetal maturity, starting of maturity, frost resistance, etc.) of frost resistant Tangerine - Tiakhara Unshiu from Japan and Saadreo and Adreula (Early ripe) has been conducted. For the application of landscape multifactor (multicomponent) method, which takes into account the role of each component in the spread of citrus, the most important parameters are the following: relief (dismemberment, slope, aspect), climate (temperature inversions, sum of active temperatures, hydrothermal coefficient, etc.), soil conditions. Using this method and morphometric analysis, it became possible ranking of frost resistant tangerine (GIS-technologies) based on the landscape, the result of which has been determined that the frost resistant tangerine varieties in western Georgia has a high yield in the higher subtropical zone.
\end{abstract}

\section{Keywords}

Agro-Landscape, Agriresource Potential, Biometric Indicators, Control Species, Zoning, Phenological Phases

How to cite this paper: Seperteladze, Z., Davitaia, E., Lamparadze, S., Memarne, G., Gaprindashvili, G. and Aleksidze, T. (2015) Agro-Landscape Zoning of West Georgia for Spreading New Varieties of Tangerine in Order to Reveal Optimal Natural Conditions. International Journal of Geosciences, 6, 1339-1352. http://dx.doi.org/10.4236/ijg.2015.612106 


\section{Introduction}

In terms of production, citrus takes second place in the world. Citruses are cultivated in more than 75 countries of the populated continents. It is surpassed by vine culture, as a result of its multi-purpose usage.

In Georgia, for cultivating of citruses, landscape response towards such problems is very important in terms of general background of the global climate changes [1]. Thereby, response of humid landscapes of the west Georgia differs from Semiarid and Arid landscapes of the east Georgia. Temperature drop-down tendency and other negative natural processes of humid landscapes of the west Georgia should be taken into account, when cultivating citruses and verifying their frost resistance level. This is proved by the fact, that in 1885 tangerines imported from Italy to Georgia for the first time failed to be launched in cultivation because of its pure frost resistance level. In recent years, it has become quite clear that old tangerine species keep degrading and the issue to replace them with new species (Tiahara Unshiu and Georgian Early ripe "Saadreo") of higher frost resistance giving the yield at the beginning of October has become urgent.

Notwithstanding the limited climate conditions, citrus-cultivation is considered to be highly intensive and effective field [2] [3]. Tangerine takes the first place among citruses, based on coverage area and importance, conditioned by its high frost resistance and cost-effectiveness. Citrus-cultivation is non-traditional field of the agriculture of Georgia.

The following is agro climate index for citrus cultivation in Georgia:

- Total of active temperatures-more than $4000^{\circ}$

- Minimum monthly humid balance-1.0

- Average of annual absolute minimums of air temperature $-4^{\circ}$

- Average temperature of the coldest month $+4,+7^{\circ}$

Citrus agriculture is mainly cultivated in Kolkheti poly-dominant forest area, in Adjara upper limit is 600 $700 \mathrm{~m}$, in Abkhazia-600 m, in Imereti-1000 meters. Upper limit of citrus plants is $600 \mathrm{~m}$ and covers the plains, Low and high hilled slopes of the foothills of the different exposure.

Citrus cultivation in the valley floor - the low places, due to temperature inversions, is impossible and there is a risk even in less severe winter conditions. However, these areas are often in regions to be discussed. The role of the slope exposure is of the utmost importance as well (Figure 1; Figure 2). The most favorable is southern exposure; even in severe winter conditions it has low risk. Higher risk is observed in the slopes of Eastern ex-

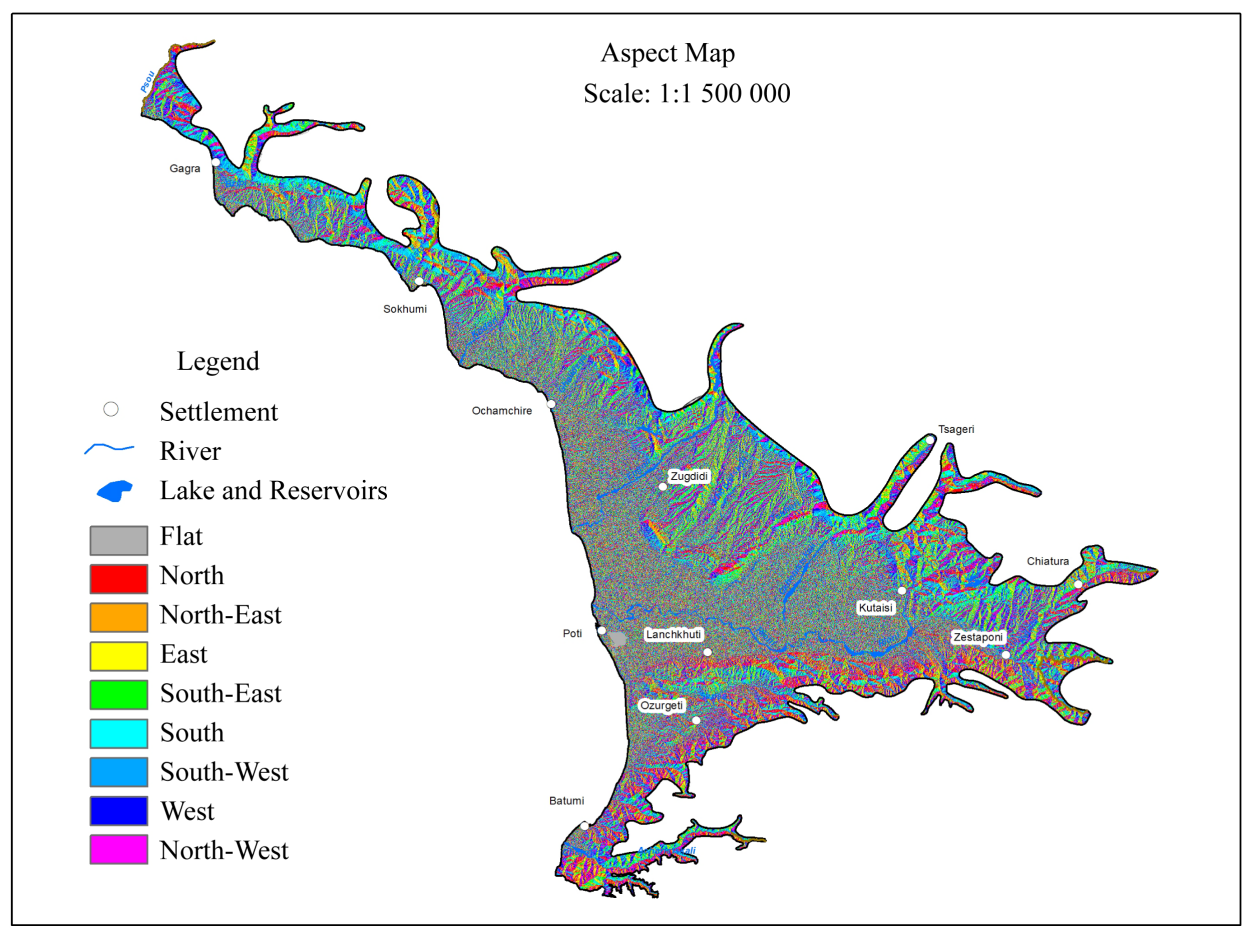

Figure 1. Aspect map. 


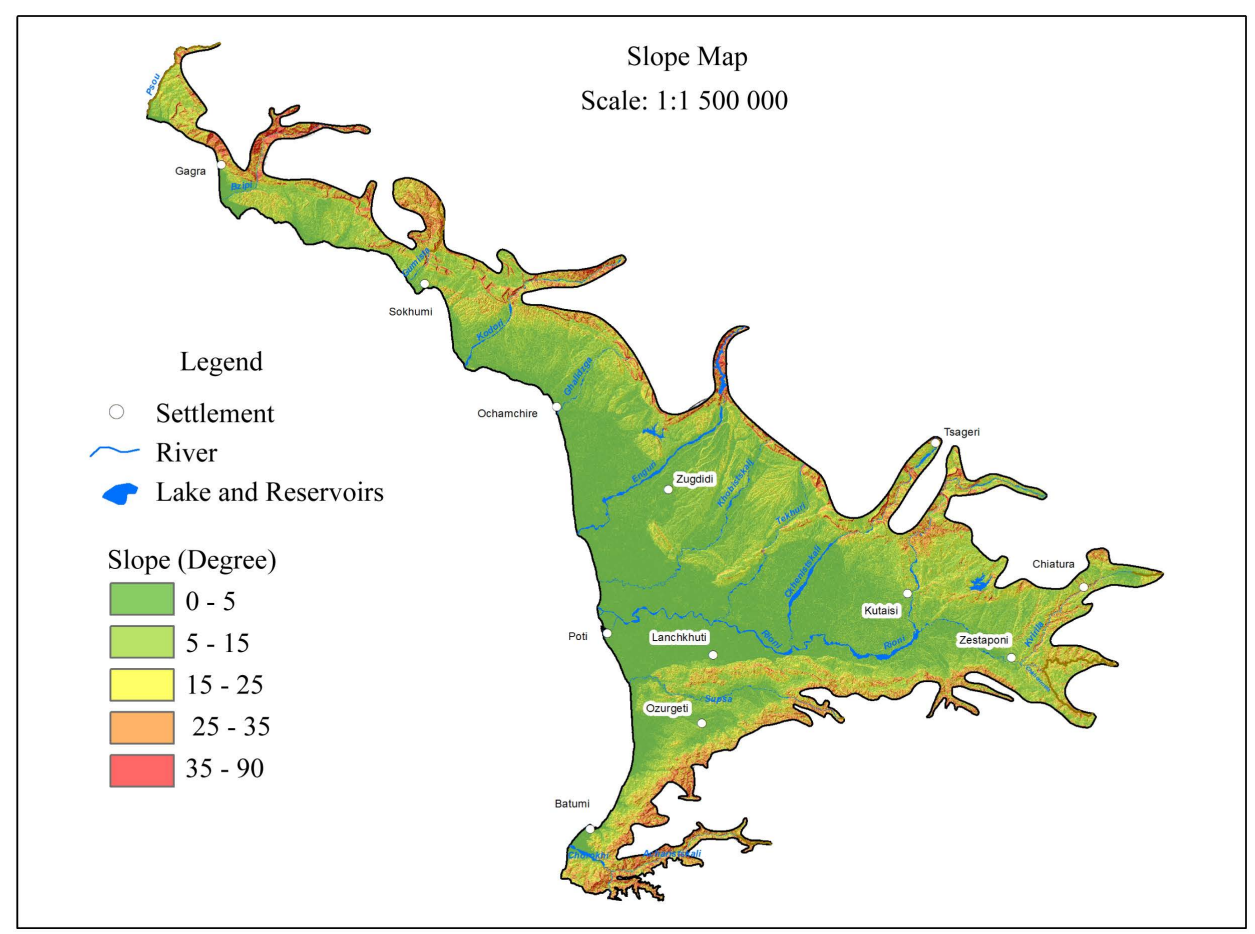

Figure 2. Slope map.

posure, frequently exposed to dry and cold winds. Relatively better situation is in the west slopes of the exposure. The exposure of North slopes is not suitable for cultivation of citrus crops, but appears to be suitable for other subtropical culture (actinidia, Tung). The best and less risky are southern slopes of hill-slopes and foothills. $5^{\circ}-10^{\circ}$ slopes could be used without any terracing and slopes more than $15^{\circ}-20^{\circ}$ needs to create terraces.

Calculations have been made in Kolkheti lowland surrounding slope and aspect distribution in percentage (Figure 3, Figure 4) and it has been revealed that the $88 \%$ slopes inclination of the region does not exceed $15^{\circ}$ $25^{\circ}$, while for tangerine Tiakhara Unshiu optimal and favorable south, south-east and south-west slopes cover $40,8 \%$ of the total area.

It is known that, for cultivating and productivity of any agricultural product, warmth and humidity are the most important factors, namely, interaction of temperature index and humidity coefficient-hydrothermal coefficient (Table 1), though other physical-geographical conditions (oro-hydrographical and soil) have important role as well. In this term, Georgia is distinguished and namely its west part. For the fact that, major part of the west Georgia (Kolkheti) is open from the west side and it is walled by medium and high mountains from other three sides, Kolkheti is characterized by: large humidity, high air temperatures, high index of sun radiation and illumination duration, seasonal changes of the west and east winds, advection of cold airs, resulting in sharp change of the weather conditions, etc. All the aforementioned affect on growth, development, productivity and geographical distribution of the agricultural products.

Notwithstanding that, west Georgia is distinguished by high level of cloudiness and excess of precipitations, high illumination between $1800-2300$ hours, total sun radiation up to $120 / 130 \mathrm{kkal} / \mathrm{cm}^{2}$ per year.

Average air temperature is $14^{\circ}-15^{\circ}$ in lower part, in mountainous part it is $12^{\circ}-13^{\circ}$. Average temperature of the coldest month - January is positive everywhere and it is $4^{\circ}-6^{\circ}$ at waterside, at foothills $+2,+3^{\circ}$. In case of cold airs (which is not rare in recent period), absolute minimum temperature drops to $-9,-10^{\circ}$ at waterside.

Considering critical temperatures (Table 2 and Figure 5), namely according to the relativity of temperatures, there was revealed possibility of citrus damage in different regions and we have received the following picture: in -40 zone (Black Sea waterside) lemon damage is to be expected once per 4 years (25\% possibility), in $-6^{\circ}$ zone, orange "Washington Naveli" may be damaged once per four years and as for the tangerine-Unshiu, it can be damaged very rarely — once per 20 years (5\% probability).

Practitioners [4] [5] have verified that vegetation of citruses starts approximately in $10^{\circ}$ temperature condi- 


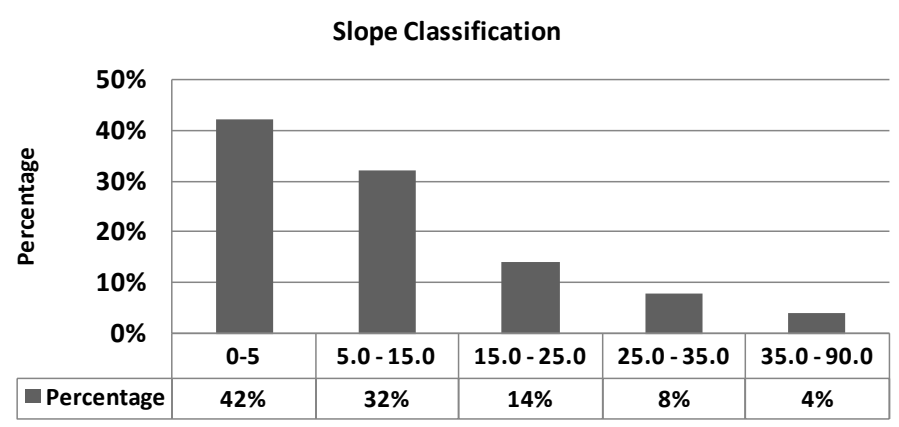

Figure 3. Slope class distribution in study area.

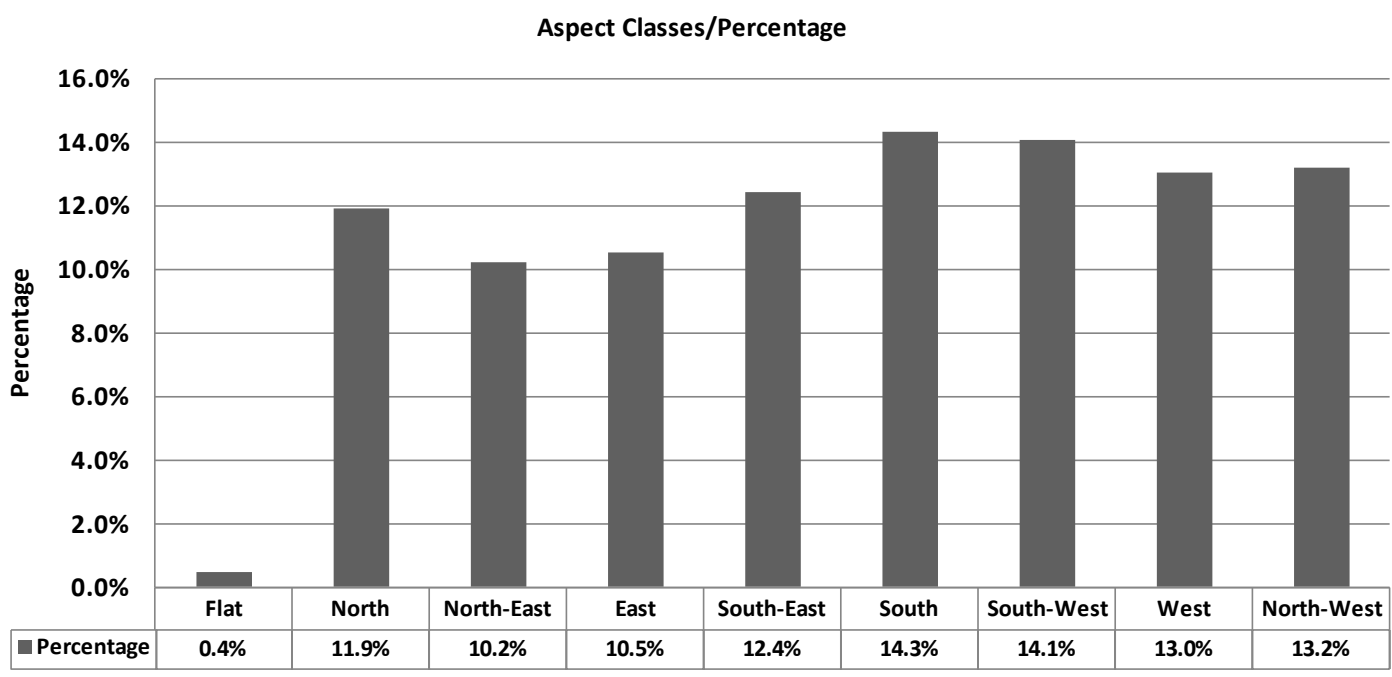

Figure 4. Aspect class distribution in study area.

Table 1. Hydrothermal coefficients of the vegetation period (HTC) of different provision.

\begin{tabular}{cccccc}
\hline & \multicolumn{5}{c}{ Provision, \% } \\
\cline { 2 - 6 } & 90 & 75 & 50 & 25 & 5 \\
\hline 1.5 & 1.0 & 1.3 & 1.5 & 1.9 & 3.1 \\
2.0 & 1.5 & 1.8 & 2.0 & 2.6 & 4.7 \\
2.5 & 1.9 & 2.3 & 2.5 & 2.9 & 5.0 \\
3.0 & 2.2 & 2.6 & 3.0 & 3.6 & 5.5 \\
3.5 & 2.5 & 3.0 & 3.5 & 4.0 & 5.9 \\
\hline
\end{tabular}

Table 2. Probability of minimum air temperature.

\begin{tabular}{cccccc}
\hline $\begin{array}{c}\text { Average of Abs. } \\
\text { minimum }\end{array}$ & 5 & 25 & 50 & Probability of minimum, \% & \\
\cline { 2 - 6 } & -10 & -7 & -4 & -2 & 1 \\
-4 & -12 & -9 & -6 & -4 & -1 \\
-6 & -14 & -11 & -8 & -6 & -3 \\
-8 & -16 & -13 & -10 & -8 & -5 \\
-10 & & & & -8 & \\
\hline
\end{tabular}




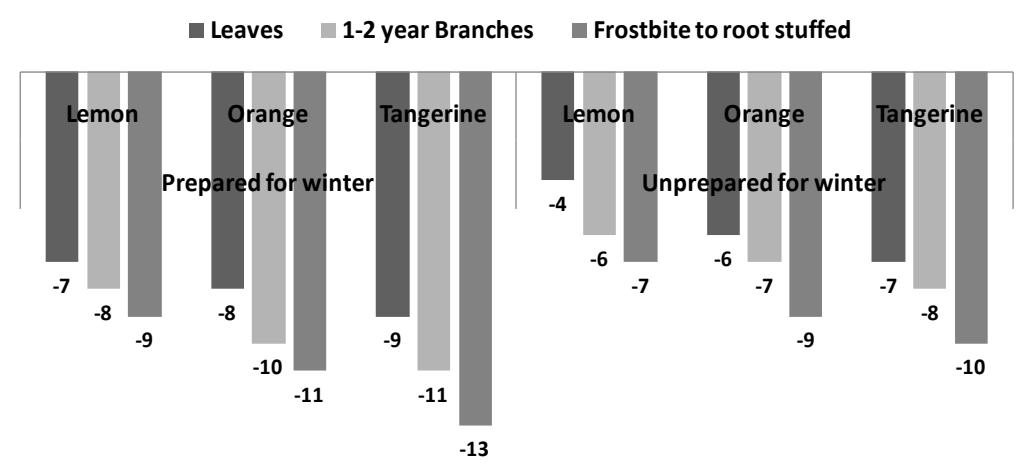

Figure 5. Critical temperatures of causing citrus damage.

tions, thereby blossoming of tangerine starts during $17^{\circ}$ average overnight temperatures, and ripening at $12^{\circ}$. Orange requires almost similar conditions; though it is more demanding towards warmth, for example, lemon needs $4000^{\circ}$ on average, during the vegetation period, tangerine needs $4200^{\circ}$, whereas orange needs $4500^{\circ}$.

Frost-resistance of citrus cultures directly refers to its composition of dry materials; whereas as much dry materials are in the plant, as frost resistance it is. This, the most tender plant is lemon, its leaves are damaged at -8 , $-6^{\circ}$, at $-7^{\circ}$ tree crown is damaged, and at $-9^{\circ}$ it dies out completely. Japanese species of tangerine shows special frost-resistance, namely (Unshiu), standing $-8^{\circ}$ frosts, though at $-12^{\circ}$ it may die out completely. One of the important features of frost-resistance is to prepare the plant for winter i.e. "training", which successfully continues, as seasonal dropping down of temperature is gradual. It is also necessary to launch additional actions: selective, agro technical and ecologic. Thus, present article focuses exactly on the later two factors, in terms of Japanese specie of the tangerine-Unshiu.

From the tangerine species spread through the Black Sea waterside subtropical zone, broad-leaved Unshiu showed vast industrial importance up to the present day; Unshiu got well adapted with local soil-climate conditions, delivering rich and stabile harvest if well cared. Consuming suitability of the fruit begins from the first decade of November and lasts until the end of this month and fruit-consuming is verified as of one calendar month, which is not optimal [6], as in late autumn, because of comparably low temperature and variable weather conditions, fruit cannot ripe in time, thus consuming and realization of fruits are decreased. Thus, this tangerine specie bears high risk and we have studied [7], some agricultural and biological characteristics of new tangerine specie, introduced from Japan (Tiahara Unshiu) based on these studies, this specie was introduced in AcharaGuria and Samegrelo citrus zone, as early ripening, fruitful and the best specie, by the State Commission of Testing Agricultural Products of Georgia.

\section{Research Methods and Initial Data}

By using Multifactor (complex) method it is possible to create Scientific argued Base of the anthropogenic transformation of environment, environmental impact assessment, its prediction, the rational nature-use, the environment protection and the conservation.

A quantitative and qualitative characteristics of geographical objects were carried out to determine the characteristics of the comparative analysis method, which enabled us to serious Geographical classification (typology) and revealing of experimental plots.

Using GIS modeling method in articifial climate laboratory was tested frost resistance skill and reaction of new plants lowering the temperature, also to determine the causal effect, their analysis and synthesis. During the analysis it was carried out to study the basic characteristics of the individual parts of the region, while the synthesis, collation and analysis of the results obtained with synthetic (complex) mapping. Using computer technologies (information retrieval and processing, etc.) it was created GIS database. For creation of Averaged Agro-climatic characteristic weighted indicators, as well as charts and diagrams mathematical method has been used. Citrus fruit qualitative characteristics of the study was done namely: Bertrand method to Define sugar, vitamins Moore, titration acidity was determined by the titration method.

There are different methods and principles of studying of multi factor analysis. Each of them plays a varied role according to its significance. An evaluation of agro-resource potential of a particular territory requires multi 
factor analysis too. Therefore, it is important to select a method which will maximum ensure the correct assessment of current situation. From this point of view, on the one hand it is important to take into account the entire complex of factors [8], but on the other hand — to demonstrate the leading factor.

As, in-depth research of morphological and biological features of the plants is a must for revealing potential possibilities of specie adaptation in changing natural conditions, analysis of Tiahara Unshiu-tangerine, introduced from Japan, including Georgian selective species, was accomplished in terms of numerical and exterior indexes of plant parts (plant height, diameter, general form, color of fruit skin and flesh, thickness of the skin, juiciness, etc.), via following evaluation plan: shoot of the plant was measured via natural measuring. Leafed part of the crown was calculated via following formula: $v=\left(3.14 \cdot \mathrm{D}^{\wedge} 2 \cdot \mathrm{H}\right) / 4$, where $\mathrm{D}$ is the average diameter of the crown, $\mathrm{H}$ is plant height; we measured the plant at $4 \mathrm{~cm}$ from engrafting place, and used formula $\mathrm{S}=\mathrm{DHK}$, (where $\mathrm{D}$-leaf width, $\mathrm{H}$-leaf length, and $\mathrm{K}$ (constant) = 0.67) for calculation of leaf space [7].

Biological characteristics of controlling and testing plants were accomplished through phonological observations (starting-ending point of the first and second growth, starting-ending point of blossoming, starting of fruit ripening and massive ripening).

For researching quality index of the fruit, sugar content was verified via Bertrand's method, vitamins via Murr method, total acidity - via titration method. Frost resistance of the plants was verified by frosting two years plants and cut branches in artificial climate laboratory, etc.

Given the fact that any of Agriculture and including tangerine fruit quality parameters are highly dependent vitamins and sugar accumulation pattern, it was conducted to determine their composition (vitamins and sugar), with different period of plant ontogenesis (Table 5), which revealed that the accumulation of this If the process intensity is determined, first of all, the vegetation period, agro-climatic characteristics of features, including: atmospheric precipitation, air temperature, hydrothermal coefficient (Tables 1-3, Table 9) and illumination quality of place. Based on which it was created agro-landscape zoning of Tiakhara Unshiu spreading (Figure 6).

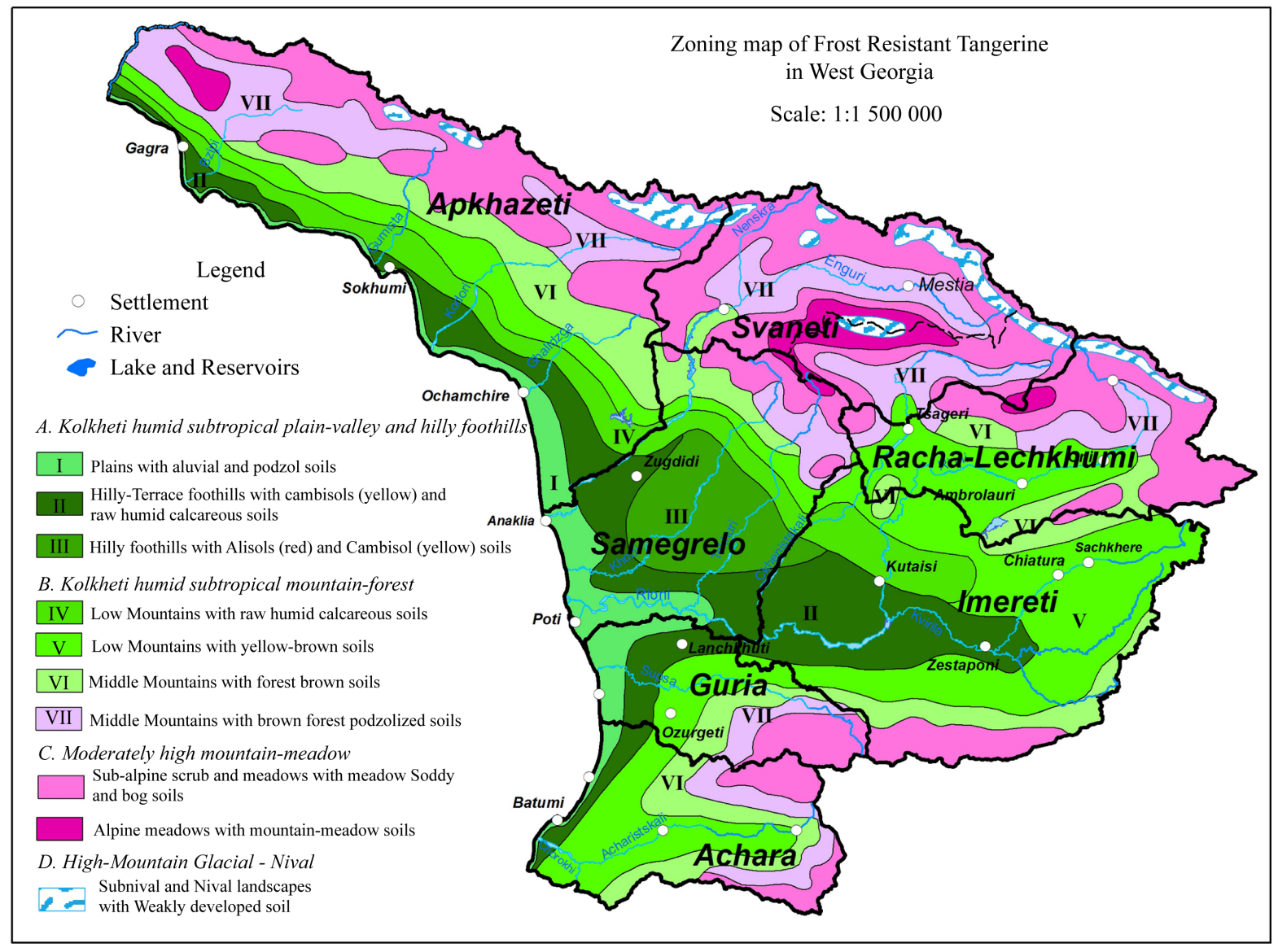

Figure 6. Zoning map of frost resistant tangerine in West Georgia. 
Vitamins are generally defined-Moore method. Group C vitamins (ascorbic acid, dehydroascorbic acid and askorbigeni) titration method defined in Tilmans paint and has been calculated using the following formula:

$\mathrm{X}=100 \mathrm{QTV} / \mathrm{V} 1 \mathrm{H}$, where Q — paint volume, $\mathrm{cm}^{3}$; T—paint titer with Ascorbic acid V-The total volume of logic $\mathrm{cm}^{3} ; \mathrm{V} 1$ - extract volume $\mathrm{cm}^{3} ; \mathrm{H}$-Tsonaki mass, g.

As for sugar, it was determined by Bertrand's method, and in this case our task was the fact that to calculate the copper oxide points, since it is strictly in line with the sugar solution, in which the copper oxide sludge separating and metal oxide oxidation, during the course of the following reaction:

$$
\begin{aligned}
& \mathrm{CuSO}_{4}+2 \mathrm{NaOH}=\mathrm{Cu}(\mathrm{OH})_{2}+\mathrm{Na}_{2} \mathrm{SO}_{4} \\
& \mathrm{Cu}(\mathrm{OH})_{2}+(\mathrm{CHOHCOO})_{2} \mathrm{NaK}=\mathrm{Cu}(\mathrm{OCHCOO})_{2} \mathrm{NaK}+2 \mathrm{H}_{2} \mathrm{O} \\
& 2 \mathrm{Cu}(\mathrm{OCHCOO})_{2} \mathrm{NaK}+\mathrm{RCOH}=\mathrm{Cu}_{2} \mathrm{O}+2(\mathrm{CHOHCOO})_{2} \mathrm{NaK}+\mathrm{RCOOH}
\end{aligned}
$$

As, introduction of frost-resistant tangerine species are very important for humid subtropical zone, we've studied frost-resistance capabilities via modeling methods, namely, in simulated climate laboratory, both with two year plants in vegetation vessels and cut branches (Figures 7-9).

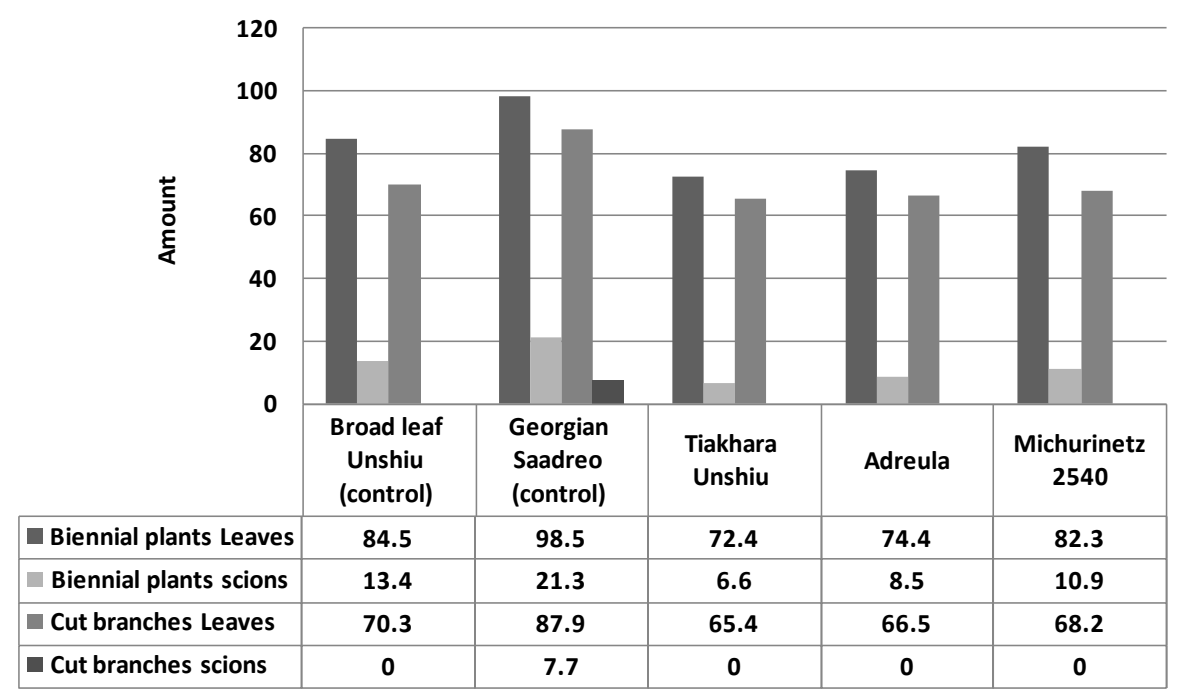

Figure 7. Cultivated and Georgian selective varieties Tangerine relative resistance-Freeze $-9^{\circ}$ temperatures, damage in \% (3-year average data).

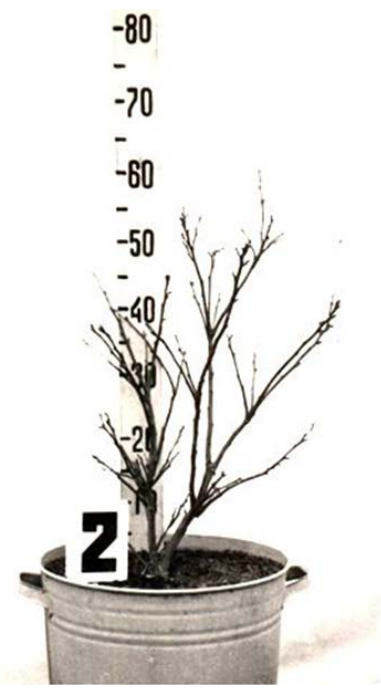

Figure 8. Tangerine varieties—Georgian “Saadreo” 2-year plant after-9 $9^{\circ} \mathrm{C}$-freeze. 


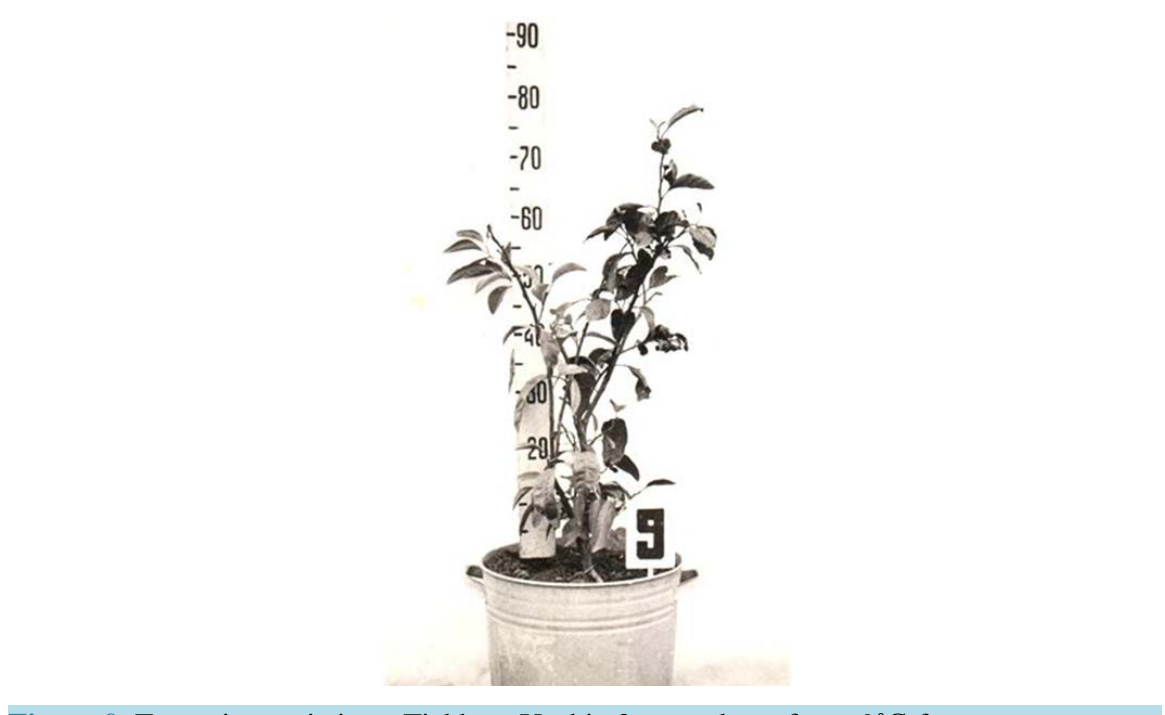

Figure 9. Tangerine varieties-Tiakhara Unshiu 2-year plant after- $-9^{\circ} \mathrm{C}$-freeze.

There is also difference between separate tangerine species in terms of mechanical and biochemical index (Table 3). Tiahara Unshiu gives the largest fruit—79.8 g and Georgian Early ripe "Saadreo"—73.8 g, whereas broad-leafed Unshiu and Georgian “Saadreo” (Early ripe) weighs 59.6 and 73.8 g, respectively.

Tangerine Tiahara Unshiu, introduced from Japan doesn't need some special agro technical measures, thus expenses for $1 \mathrm{~h}$ cultivation and nursing are not different from the same expenses of the Georgian selective species.

Cost-effectiveness of tangerine species depends on the following specifications: hectare productivity, expenditure on total production, nominal price of unit product and total net profit (Table 4).

As Table 4 shows, in terms of cost-effectiveness, the following tangerine species are more attractive and interesting: Tiahara Unshiu, early ripe (Adreula) and Michurinetz 2540, which comparing with broad-leafed Unshiu brings up to 34\% - 57\% additional profit per hectare and in comparing with the Georgian Early Rip "Saadreo" $20 \%-42 \%$.

Thus, profitability level of introduced tangerine Tiahara Unshiu and Georgian selective species: Adreula and Michurinetz 2540 reaches 114\% - 140\%, when controlling species shows only 94\% - 100\% (broad-leafed Unshiu, Georgian Early Ripe "Saadreo").

Correspondingly, for agricultural profitability, natural (landscape), namely, agro climate resources (duration of sun illumination, total of active temperatures, precipitations, humidity of soil and air, etc) should be used as much as possible, based on which, aforementioned characteristics can be used effectively in different regions, aiming developing of agricultural products and their rational distribution-planting (zoning). We have marked out 7 agro climate zones [9] in west Georgia (Table 5).

Based on the data base received from accomplished studies [10], it was verified that 3 agro climate zones (I, II, III) are distinguished with suitable physical-geographical (soil-climate) conditions for cultivation of citrus cultures in west Georgia (Table 6).

In 1980 in Achara region, tangerine held 4500 ha and now it is 5600 ha, citrus cultivation led to the destruction of Kolkheti poly-dominant forests in Achara and in whole west Georgia up to 500 - 600 m. Their particular areas can be found in deep gorges and in protected areas.

Adjara is a mountainous region, where the forests and bushes cover 191 thousand ha, which is 66\% of the total area. 23,289 ha come on Khelvachauri Municipality and 23,279 ha of Kobuleti Municipality (2010 statistics).

The total area of bushes and forests in Khelvachauri and Kobuleti Municipality bellow 300 m covers 763 and 1215 ha respectively, where the tangerines have the best soil and climatic conditions. In recent years, the area of bushes increased at the expense of tea plantations desolation (destruction).

Main agricultural crops in Kobuleti and Khelvachauri Municipalities are tea and citrus, but in the $90 \mathrm{~s}$ by the difficult economic situation in the country drastically reduced the tea plantations and citrus plantations were considerably reduced. 
Table 3. Cultivated and Georgian selective varieties tangerine mechanical and biochemical composition of the fruit (5-year average data).

\begin{tabular}{|c|c|c|c|c|c|c|c|c|c|c|c|c|}
\hline \multirow{3}{*}{ \# } & \multirow{3}{*}{ Variety name } & \multicolumn{5}{|c|}{ Mechanical composition \% } & \multicolumn{4}{|c|}{$\begin{array}{c}\text { Juice composition in } 100 \text { milliliters } \\
\text { calculation }\end{array}$} & \multirow{3}{*}{$\begin{array}{l}\text { Sugar } \\
\text { acidity } \\
\text { ratio }\end{array}$} & \multirow{3}{*}{$\begin{array}{l}\text { Degustation } \\
\text { rate } \\
\text { (intensity) }\end{array}$} \\
\hline & & \multirow{2}{*}{$\begin{array}{l}\text { Average } \\
\text { weight of } \\
\text { the fruit, } \\
\text { g }\end{array}$} & \multirow{2}{*}{ Skin } & \multirow{2}{*}{ Pulp } & \multicolumn{2}{|c|}{$\begin{array}{l}\text { The yield of } \\
\text { juice }\end{array}$} & \multirow{2}{*}{$\begin{array}{c}\text { Dry } \\
\text {-substance, } \\
\text { \% }\end{array}$} & \multirow{2}{*}{$\begin{array}{c}\text { Citric acid, } \\
\text { calculated } \\
\text { on its } \\
\text { titratable } \\
\text { acidity }\end{array}$} & \multirow{2}{*}{$\begin{array}{l}\text { Vitamin } \\
\text { C mg/\% }\end{array}$} & \multirow{2}{*}{$\begin{array}{l}\text { Sugar } \\
\text { sum }\end{array}$} & & \\
\hline & & & & & $\begin{array}{l}\text { From } \\
\text { pulp }\end{array}$ & $\begin{array}{l}\text { From } \\
\text { fruit }\end{array}$ & & & & & & \\
\hline 1 & $\begin{array}{l}\text { Broad leaf Unshiu } \\
\text { (control) }\end{array}$ & 59.6 & 28.7 & 71.3 & 70.0 & 51.1 & 9.1 & 1.04 & 35.6 & 7.6 & 7.3 & 75.1 \\
\hline 2 & $\begin{array}{l}\text { Georgian Early Ripe, } \\
\text { "Saadreo" (control) }\end{array}$ & 73.8 & 26.9 & 73.1 & 63.8 & 46.2 & 9.2 & 1.13 & 36.9 & 7.8 & 6.9 & 75.9 \\
\hline 3 & Tiakhara Unshiu & 79.8 & 24.1 & 75.9 & 74.0 & 55.6 & 9.3 & 0.91 & 38.1 & 7.9 & 8.7 & 80.2 \\
\hline 4 & “Adreula” (early ripe) & 71.1 & 27.4 & 72.6 & 69.0 & 49.9 & 9.6 & 1.11 & 34.7 & 7.8 & 7.0 & 78.6 \\
\hline 5 & Michurinetz 2540 & 69.5 & 29.5 & 70.5 & 71.3 & 50.5 & 9.6 & 1.17 & 33.6 & 7.7 & 6.6 & 73.9 \\
\hline
\end{tabular}

Table 4. Georgian selective varieties of mandarins and introduced major economic indicators in hectare (10-year average data).

\begin{tabular}{|c|c|c|c|c|c|c|}
\hline \# & Variety name & Productivity c/h & $\begin{array}{l}\text { Total production } \\
\text { value (USD) }\end{array}$ & $\begin{array}{l}\text { Total expenses } \\
\text { (USD) }\end{array}$ & $\begin{array}{l}1 \text { quintals of } \\
\text { production cost } \\
\text { (USD) }\end{array}$ & $\begin{array}{l}\text { Net income } \\
\text { (USD) }\end{array}$ \\
\hline 1 & Broad leaf Unshiu (control) & 424 & 12863 & 6917 & 16.3 & 6471 \\
\hline 2 & $\begin{array}{l}\text { Georgian Early Ripe "Saadreo" } \\
\text { (control) }\end{array}$ & 455 & 14368 & 7184 & 15.78 & 7184 \\
\hline 3 & Tiakhara Unshiu & 552 & 17431 & 7263 & 13.15 & 10168 \\
\hline 4 & “Adreula” (early ripe) & 538 & 16989 & 7362 & 13.68 & 9627 \\
\hline 5 & Michurinetz 2540 & 513 & 16200 & 7560 & 14.73 & 8640 \\
\hline
\end{tabular}

Table 5. Zones, Altitude from sea level (m), Actual temperature total (more than 10\%), Average of absolute and minimal temperature $\left({ }^{\circ} \mathrm{C}\right)$, Nonfreezing days.

\begin{tabular}{ccccc}
\hline Zone & $\begin{array}{c}\text { Altitude from sea level } \\
(\mathrm{m})\end{array}$ & $\begin{array}{c}\text { Actual temperature total } \\
(\text { more than } 10 \%)\end{array}$ & $\begin{array}{c}\text { Average of absolute and minimal } \\
\text { temperature }\left({ }^{\circ} \mathrm{C}\right)\end{array}$ & Nonfreezing days \\
\hline I & $0-350$ & $4000-4500$ & -3 & $280-310$ \\
II & $351-560$ & $3500-4000$ & $-14-16$ & $190-275$ \\
III & $561-780$ & $3000-3500$ & $-18-8$ & $186-267$ \\
IV & $781-990$ & $2500-3000$ & $-12-22$ & $175-216$ \\
V & $991-1250$ & $2000-2500$ & $-14-23$ & $140-205$ \\
VI & $1251-1750$ & $1500-2000$ & $-15-28$ & $120-180$ \\
VII & $1751-2100$ & $1000-1500$ & $-19-29$ & $100-150$ \\
\hline
\end{tabular}

In 1990, from 8529 hectares of citrus, were produced 152730 tons of fruit, and in 2000 it was received 39320 tons from the 7895 hectares fruit. Citrus plantations declining trend continued until 2005, which was mainly due to the sale of fetal problems, incorrect land privatization and cultivation other perennial crops (nuts, kiwi, blueberry). Today there are 4500 ha of citrus plants produce about 100 - 110 thousand tons of fruit, which is about 22 - 25 tons per ha per annum. Low productivity is considered that it is needed to update variety, which should be replaced by High-yield productivity varieties. It is in these sorts of Tangerine Tiakhara Unshiu appears that good agricultural background in the 50 - 60 tons per hectare harvested. 
Table 6. Main characteristics of different horizons.

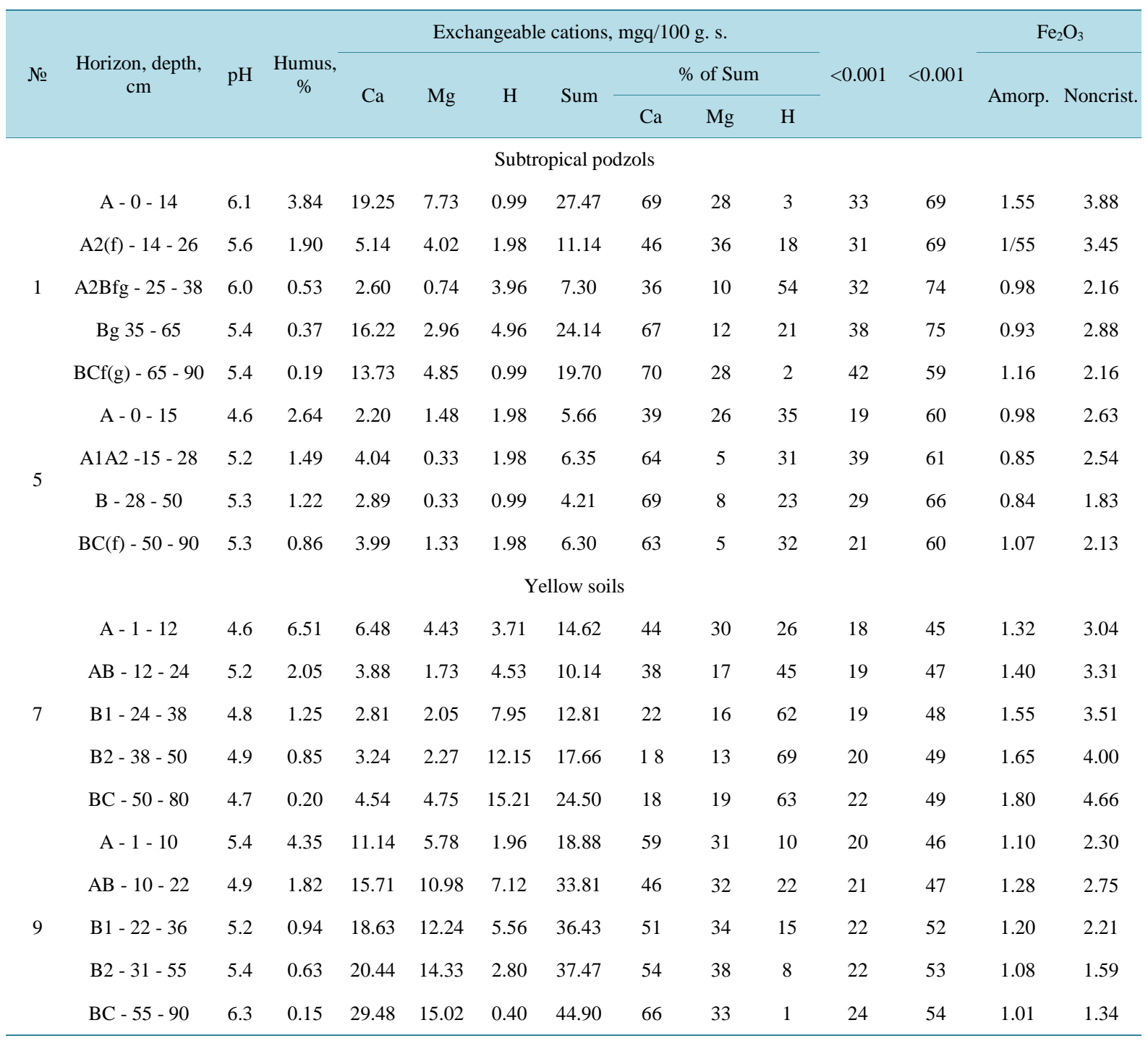

In Industrial plants 95\% holds Tangerine broad leave Unshiu, the remaining 5\% hold other breeds (Georgian Early Ripe "Saadreo", Kovano-Vase, and et al.).

For improvement of the range of breed and productivity in Achara citrus farmer farms it is implemented Tiakhara Unshiu Tangerine, which gives 30\% more fruits and brewing 30 - 35 days early as usual tangerine.

Since 2005, the number of Tiakhara Unshius is increasing every year, today it is 55 hectares. The new species of shrubs and plants are built mainly former tea areas, on removed old bushes and trees (amortized) place.

In Kobuleti and Khelvachauri municipality it can be planted 30 - 35 hectares of new plantations of Tiakhara Unshiu tangerines every year, for which there are farms of micro-nurseries, where it is possible production of 35 - 40 thousand high-quality implants of Tiakhara Unshiu annually.

For cultivation of citrus, place with the most suitable natural conditions is Achara (Table 7). Generally, there are 5 agro climate zones in Achara, whereas generally two of them is most suitable in terms of citrus cultivation and high productivity—in 500 - $500 \mathrm{~m}$ above sea level: I zone (50 - 200 above sea level)—total of active temperatures more than $4000^{\circ}$; number of precipitations in warm period of the year is $1360-1500 \mathrm{~mm}$; last frosting -4; III -15. III, first frosting -2. XII -7. I.; number of frost free days-246 - 304; dominating soil type-subtropical podzol, red soils and alluvial; II zone (200 - $500 \mathrm{~m}$ above sea level) is more vast and mainly includes Kobuleti and Khelvachauri Municipalities. Total of active temperatures is $3000^{\circ}-4000^{\circ}$; precipitation in warm 
Table 7. Basic agro-climatic characteristics in Achara Region.

\begin{tabular}{ccccccccc}
\hline $\begin{array}{c}\text { Meteorological } \\
\text { station }\end{array}$ & Height $(\mathrm{m})$ & $\begin{array}{c}\text { Sum of active } \\
\text { temperatures } \\
(\geq 100)\end{array}$ & $\begin{array}{c}\text { Amount of } \\
\text { precipitation, } \\
\text { mm }\end{array}$ & $\begin{array}{c}\text { Relative } \\
\text { humidity } \\
\text { of air, } \%\end{array}$ & $\begin{array}{c}\text { Air humidity } \\
\text { deficit, Mb }\end{array}$ & $\begin{array}{c}\text { Frost-free } \\
\text { days }\end{array}$ & HTC \\
\hline Akhalsheni & 100 & 4300 & 1470 & 78 & 5.0 & 304 & 3.4 \\
Batumi & 15 & 4320 & 1440 & 80 & 4.7 & 302 & 3.3 \\
Keda & 290 & 3880 & 800 & 77 & 5.4 & 257 & 2.0 \\
Kobuleti & 5 & 3990 & 1360 & 81 & 4.3 & 246 & 3.4 \\
Chakvi & 15 & 4230 & 1500 & 80 & 4.7 & 282 & 3.5 \\
\hline
\end{tabular}

period of the year is $800-1330 \mathrm{~mm}$; last frost -13 . III -26 . III, first frost -6 . XII -1 . I.; number of frost free days—255 - 273; dominating soil type_-red soils and yellow soils.

Thus, based on research, frost resistant tangerine varieties growing area can be increased, and it is successful in the next, the third zone-600 - $700 \mathrm{~m}$ above sea level.

Second region in terms of subtropical natural condition is Apkhazeti (Table 8). Only two from five climate zones allows cultivating subtropical cultures and receiving quality product.

I zone-includes water side and lower hilly regions (50 - $300 \mathrm{~m}$ above sea level). Total of active temperatures more than 40000; precipitations in warm period of the year are $710-1010 \mathrm{~mm}$; last frost -10 . III -20 . III, first frost -13. XII -25. XII; number of frost free days 269 - 291; dominating soil type-subtropical podzol, yellow podzolic soil, yellow soil and red soils. II zone (300 - $500 \mathrm{~m}$ above sea level). Total of active temperatures $3000^{\circ}$ - $4000^{\circ}$; precipitations in warm period of the year are 1100 - $1400 \mathrm{~mm}$; last frost -25 . III -28 . III, first frost -2 . XII -6. XII.; number of frost free days-251 - 260; dominating soil type: red soils_-podzolic, yellow soil— podzolic, subtropical podzol, carbonate.

Like Adjara, in Apkhazeti region based on research, it is possible to recommend that frost resistant tangerine varieties can be expended above 500 - $700 \mathrm{~m}$ height of agro-landscape zone.

In west Georgia, Guria is the part distinguished with humid subtropical conditions and generally, we have 5 agro climate zones here, two of them are subtropical (Table 9).

I zone (50 - $200 \mathrm{~m}$ above sea level) includes water side and lower hilly regions: total of active temperatures is more than 40000; precipitations in warm period of the year are $700-11000 \mathrm{~mm}$; last frost -10 . III -18 . III, first frost -16. XII -25. XII; number of frost free days-274 - 290; dominating soil type—subtropical—podzol, alluvial-acid, red soils. II zone-(200 - $500 \mathrm{~m}$ above sea level) shows the following characteristics: total of active temperatures is $4000^{\circ}-3500^{\circ}$; precipitations in warm period of the year are $9000-1200$ mm; last frost -15 . III -20. III, first frost -10. XII -20. XII; number of frost free days-250 - 270; dominating soil type: podzolic, yellow soils, red soil. Based on research third zone was added on Guria subtropical zone, 500 - $700 \mathrm{~m}$ a.s.l, where it will have high yield.

In Samegrelo, only two zones from 5 agro climate zones are having physical-geographical conditions suitable for subtropical cultures (Table 10), 50 - $500 \mathrm{~m}$ above sea level.

I zone-includes Black Sea water side and lower hilly regions (50 - $200 \mathrm{~m}$ above sea level). Total of active temperatures is more than 40000; precipitations in warm period of the year are 800 - $1200 \mathrm{~mm}$; last frost - 15 . III -20. III, first frost -2. XII -7. XII.; number of frost free days-250 - 260; dominating soil type-red soil— podzolic, peat bog, yellow soils. I zone (200 - $500 \mathrm{~m}$ above sea level); total of active temperatures $-3700^{\circ}$ $4200^{\circ}$; precipitations in warm period of the year are $1160-1220 \mathrm{~mm}$; last frost -21 . III -29 . III, first frost -23. XI -6. XII; number of frost free days-236 - 257; dominating soil type-yellow soil-podzolic, subtropical podzol. In comparing with other regions, Imereti region of the west Georgia gives less suitable physicalgeographical conditions for cultivation of subtropical cultures (Table 10) and that is why, we have only one subtropical zone (hypsometric first) here. Based on research it is recommended spreading of frost resistant tangerine variety in third zone (500 - $700 \mathrm{~m}$ a.s.l.). As for Imereti region, here traditionally regarding physicalgeographical conditions citrus zone is first zone 0 - $300 \mathrm{~m}$ a.s.l.

I zone includes plain of lower Imereti and hilly part of upper Imereti (until 200 - 300 m above sea level). Total of active temperatures is more than $4000^{\circ}$; precipitations in warm period of the year are 600 - 1000 mm; last 
Table 8. Basic agro-climatic characteristics in Apkhazeti Region.

\begin{tabular}{cccccccc}
\hline $\begin{array}{c}\text { Meteorological } \\
\text { station }\end{array}$ & Height $(\mathrm{m})$ & $\begin{array}{c}\text { Sum of active } \\
\text { temperatures } \\
(\geq 100)\end{array}$ & $\begin{array}{c}\text { Amount of } \\
\text { precipitation, } \\
\text { mm }\end{array}$ & $\begin{array}{c}\text { Relative } \\
\text { humidity of } \\
\text { air, } \%\end{array}$ & $\begin{array}{c}\text { Air humidity } \\
\text { deficit, Mb }\end{array}$ & $\begin{array}{c}\text { Frost-free } \\
\text { days }\end{array}$ & HTC \\
Gagra & 25 & 4330 & 710 & 79 & 5.1 & 273 & 1.6 \\
Gali & 48 & 4260 & 970 & 81 & 5.1 & 250 & 2.3 \\
Gudauta & 46 & 4430 & 790 & 77 & 5.6 & 288 & 1.9 \\
Duripshi & 260 & 4100 & 1010 & 76 & 5.9 & 263 & 2.5 \\
Gulripshi & 20 & 4400 & 820 & 75 & 5.8 & 294 & 1.9 \\
Ochamchire & 5 & 4150 & 770 & 84 & 4.0 & 262 & 1.8 \\
Sokhumi & 7 & 4060 & 820 & 78 & 5.4 & 295 & 1.8 \\
\hline
\end{tabular}

Table 9. Basic agro-climatic characteristics in Guria region.

\begin{tabular}{ccccccccc}
$\begin{array}{c}\text { Meteorological } \\
\text { station }\end{array}$ & Height $(\mathrm{m})$ & $\begin{array}{c}\text { Sum of active } \\
\text { temperatures } \\
(\geq 100)\end{array}$ & $\begin{array}{c}\text { Amount of } \\
\text { precipitation, } \mathrm{mm}\end{array}$ & $\begin{array}{c}\text { Relative } \\
\text { humidity of air, } \\
\%\end{array}$ & $\begin{array}{c}\text { Air humidity } \\
\text { deficit, Mb }\end{array}$ & Frost-free days & HTC \\
\hline Anaseuli & 70 & 4150 & 1140 & 79 & 4.0 & 277 & 2.7 \\
Acana & 160 & 4020 & 1130 & 80 & 5.0 & 272 & 2.8 \\
Dablatsikhe & 250 & 4160 & 980 & 74 & 6.3 & 272 & 2.3 \\
Supsa & 5 & 4060 & 1370 & 83 & 4.2 & 267 & 3.3 \\
Ureki & 10 & 4380 & 1180 & 80 & 4.6 & 288 & 2.7 \\
\hline
\end{tabular}

Table 10. Basic agro-climatic characteristics in Samegrelo region.

\begin{tabular}{cccccccc}
\hline $\begin{array}{c}\text { Meteorological } \\
\text { station }\end{array}$ & Height (m) & $\begin{array}{c}\text { Sum of active } \\
\text { temperatures } \\
(\geq 100)\end{array}$ & $\begin{array}{c}\text { Amount of } \\
\text { precipitation, } \\
\mathrm{mm}\end{array}$ & $\begin{array}{c}\text { Relative } \\
\text { humidity of } \\
\text { air, } \%\end{array}$ & $\begin{array}{c}\text { Air humidity } \\
\text { deficit, Mb }\end{array}$ & Frost-free days & HTC \\
\hline Abasha & 24 & 4310 & 790 & 81 & 2.2 & 270 & 1.8 \\
Anaklia & 3 & 4250 & 900 & 83 & 1.8 & 263 & 2.1 \\
Zugdidi & 100 & 4160 & 1010 & 79 & 2.0 & 250 & 2.4 \\
Martvili & 180 & 4210 & 1110 & 76 & 1.2 & 257 & 2.6 \\
Mukhuri & 270 & 4260 & 1430 & 73 & 2.5 & 276 & 3.3 \\
Senaki & 31 & 4520 & 1000 & 76 & 2.7 & 288 & 2.2 \\
Tsalenjikha & 200 & 4000 & 1160 & 77 & 2.6 & 255 & 2.9 \\
Kheta & 80 & 4560 & 1100 & 78 & 3.0 & 275 & 2.4 \\
Chkhorotsku & 180 & 4130 & 1200 & 77 & 2.7 & 250 & 2.9 \\
\hline
\end{tabular}

frost -2 . III -5 . III, first frost -25 . XI -30 . XI; number of frost free days -251 - 274; dominating soil type_alluvial—carbonate, subtropical—podzol, carbonate, yellow soils (Table 11). Based on research, in this region frost resistant varieties could be developed in third hypsometrical zone (500 - $600 \mathrm{~m}$ a.s.l).

\section{Main Results}

Based on the experiment-morphological, biochemical researches and landscape-multifactor methods following result were marked out: 
Table 11. Basic agro-climatic characteristics in Imereti region.

\begin{tabular}{cccccccc}
\hline $\begin{array}{c}\text { Meteorological } \\
\text { station }\end{array}$ & Height (m) & $\begin{array}{c}\text { Sum of active } \\
\text { temperatures } \\
(\geq 100)\end{array}$ & $\begin{array}{c}\text { Amount of } \\
\text { Precipitation, } \\
\mathrm{mm}\end{array}$ & $\begin{array}{c}\text { Relative } \\
\text { Humidity of } \\
\text { air, } \%\end{array}$ & $\begin{array}{c}\text { Air humidity } \\
\text { deficit, Mb }\end{array}$ & Frost-free days & HTC \\
\hline Dimi & 180 & 4300 & 670 & 72 & 7.5 & 278 & 1.5 \\
Vani & 70 & 4330 & 680 & 74 & 7.0 & 278 & 1.5 \\
Sakara & 55 & 4330 & 600 & 72 & 7.9 & 250 & 1.4 \\
Samtredia & 25 & 4470 & 750 & 77 & 6.4 & 284 & 1.6 \\
Tskaltubo & 120 & 4500 & 990 & 75 & 7.3 & 253 & 2.2 \\
Chiatura & 400 & 4090 & 600 & 73 & 7.2 & 255 & 1.4 \\
Kharagauli & 350 & 4090 & 730 & 73 & 7.8 & 245 & 1.7 \\
Khoni & 120 & 4410 & 1000 & 76 & 6.9 & 272 & 2.2 \\
\hline
\end{tabular}

1. Using Landscape-Multifactor method it was conducted optimal natural condition selection-assessment and ranking of frost resistance tangerine types;

a) Relief basic morphometric parameters (slope inclination and aspect) and the qualitative characteristics.

b) Analysis and Synthesis of Soil and Climatic characteristics.

2. Morphological analysis (biometric index, starting-ending point of the first and second growth, startingending point of blossoming, starting of ripening and massive ripening, harvest, mechanical and biochemical composition of the fruit, tasting, storage properties, cost-effectiveness and frost (winter) resistance) of the tangerine-TiaharaUnshiu, introduced from Japan and from Georgia was accomplished.

3. For researching potential capabilities of specie adaptation and quality index of the fruit, sugar content was verified via Bertrand's method, vitamins via Murr method, total acidity—via titration method. Frost resistance of the plants was verified by frosting two years plants and cut branches in artificial climate laboratory, etc.

4. It is recommended to cultivate in the first citrus zone (total of active temperatures more than 40000) of the west Georgia), the following tangerine species: broad-leaved Unshiu, Georgian "Saadreo", Tiahara Unshiu, Adreula and Michurinetsi 2540, and tangerine early ripe species (Georgian "Early Ripe" Saadreo, Tiahara Unshiu and "Adreula") are recommended to cultivate in the regions with less then $4000^{\circ}$ of total active temperatures in vegetation period, such regions include (zone II). The relatively high upgradient (III) zone, where the sum of active temperatures during the vegetation period is less than 40000, which is not sufficient for growth in culture of tangerine, it is recommended to be planted "Saadreo" (early ripe), frost resistant varieties: Georgian "Saadreo", tiakhara Unshiu and "Adreula”.

\section{Acknowledgements}

This research would not have been possible without the support of many people and also without using many scientific researches done by the staff of the Department of Geography (Faculty of Exact and Natural Sciences) of Ivane Javakhishvili Tbilisi State University and Batumi Shota Rustaveli State University. The authors of the work express their gratitude to all them.

\section{References}

[1] Elizbarashvili, N., Meladze, G. and Seperteladze, Z. (2014) Climate Change and the Possible Migration of the Population in Georgia. Tourism, Environment and Ecology in the Mediterranean Region. In: Efe, R. and Öztürk, M., Eds., Tourism, Environment and Ecology in the Mediterranean Region, Cambridge Scholars Publishing, Cambridge, United Kingdom, 447-457.

[2] Agricultural Sector (2011) Invest in Georgia, Ripe for Investment. http://www.investingeorgia.org/upload/file/Georgia\%20brochure\%2020-01-12\%20Agriculture.pdf

[3] Geography of Georgia (2003) Part II. Social-Economic Geography. Tbilisi. In: Georgian, 375 p.

[4] Meladze, G. and Meladze, M. (2012) Agri Climatic Resources of Western Regions of Georgia. Institute of Hydrometeorology at the Technical University. Tbilisi, In: Georgian, 248-426. 
[5] Seperteladze, Z., Davitaia, E., Memarne, G., Xalvashi, N. and Gaprindashvili, G. (2014) Natural Environment Zoning of West Georgia for Identifying the Perspective Regions of Actinidia chinensis Planch Culture Spreading. IJSRGlobal Journal for Research Analysis, 3, 82-86.

[6] Lamparadze, Sh. (2002) A New Variety of Tangerine Tiaharasatsumas. Abstracts of the International Scientific and Technical Conference "Integration of Science and Industry in the Development of Subtropical Crop”. Sochi, 68-70.

[7] Lamparadze, Sh. (2008) Tangerine Variety Super "Saadreo” Miho-Vase Yield Fruits and Biochemical Indicators. The State Agricultural University, International Scientific Conference "Crop Genetic Resources and Their Use in Agriculture” Collected Papers, Tbilisi, 236-238.

[8] Arkhipov, U.R., Blajko, N.I., Grigoriev, S.V., et al. (1986) Mathematical Methods in Geography. Kazan University, Kazan City, 95-108.

[9] Urushadze, T., Seperteladze, Z. and Davitaya, E. (2012) Natural Resource Potential of Western Georgia and Territorial Management of Agri Landscapes. Bulletin Georgian National Academy of Sciences, 4, 74-78.

[10] Seperteladze, Z., Davitaia, E., Alexsidze, T., Ruxadze, N. and Gaprindashvili, G. (2014) Assessment of Agro-Resource Potential of the Western Georgia and Physical-Geographical Zoning. IJSR-International Journal of Scientific Research, 3, 170-172. 